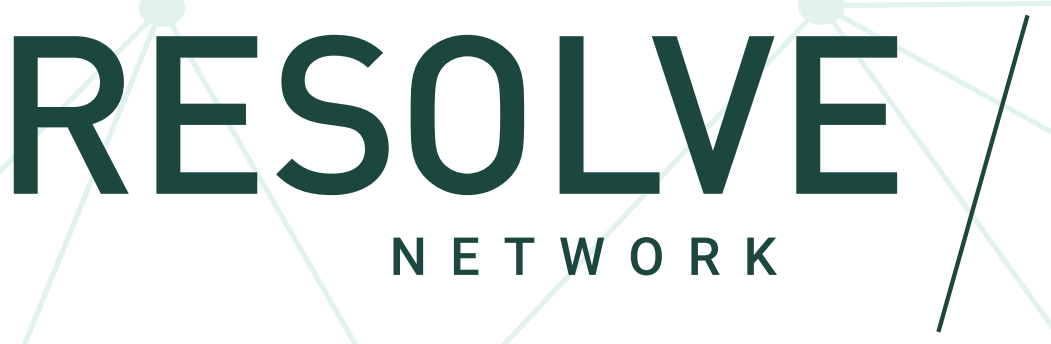

\title{
Demystifying Gender Analysis \\ for Research on Violent Extremism
}

Phoebe Donnelly 


\section{ABSTRACT}

Incorporating a gender analysis into research on violent extremism and countering violent extremism ( $P / C V E$ ) leads to more accurate conclusions about violent extremism and violent extremist organizations (VEOs). When scholars, policymakers, and activists pay attention to gender dynamics, they gain new insights about power, identities, and relationships. Researchers cannot ignore the gender dimension of violent extremism because VEOs understand the importance of gender and leverage ideas about gender for their own advantage. Despite the clear benefits from incorporating gender into the research process, most researchers are not trained on gender analysis and therefore cannot envision what it looks like in practice. This chapter outlines some of the key steps in a gender analysis, including asking questions about the different experiences of men, women, boys, and girls; tracing power dynamics; recognizing intersectional identities; analyzing context; and challenging existing knowledge and conventions. The goal of this chapter is to demystify gender analysis so that it becomes an approachable tool researchers choose to use to gain a more accurate picture of contexts of violent extremism. 


\section{INTRODUCTION}

Researchers and practitioners have long been aware of the ways in which gender and violent conflict intersect. More recently there has been an increase in research around gender dynamics in contexts of violent extremism, specifically around the role women and girls play in violent extremist organizations (VEOs) ${ }^{1}$ and forms of gender-based violence (GBV) perpetrated by VEOs. ${ }^{2}$ Without gender research, it would be difficult to make sense of the composition of VEOs, how they are able to recruit and retain members, why they choose different forms of violence, and what happens when they start to lose territory. Researchers and practitioners who focus explicitly on gender cannot be the only ones incorporating gender analysis. Governments, donors, and scholars have recognized the value of a gender analysis and are encouraging incorporating gender into an analysis of contexts of violent extremism. ${ }^{3}$ While this is a positive step, it should not be assumed that most researchers know how to do a gender analysis or understand the specific components and concepts encompassed within it. Gender analysis is a tool and a skill like any other used to analyze complicated contexts, including those where VEOs operate.

This chapter aims to show scholars and policymakers the key components and processes of gender analysis, provide useful information and examples in designing a gender analysis, and demonstrate how a gender analysis can lead to a better understanding of contexts where violent extremism is present. It describes some of the key steps of a gender analysis, like asking questions about the different experiences of men, women, boys, and girls; tracing power dynamics; recognizing intersectional identities; analyzing context; and challenging existing knowledge and conventions. A gender analysis pays attention not only to women, but to the particular experiences, expectations, relationships, and access to power for men, women, boys, girls, and sexual and gender minorities (SGMs). In addition to looking at women, men, boys, and girls, in a gender analysis, one examines different ideas about masculinities and femininities. Throughout, this chapter primarily references four gendered groups: men, women, boys, and girls. This practice is not to deny the existence of gender or sexual minorities (discussed in greater detail in Table 1). However, the binaries of men and women or boys and girls are often essential to VEOs that usually privilege what is considered masculine in contrast to that which is considered feminine.

1 Meredith Loken and Anna Zelenz, "Explaining Extremism: Western Women in Daesh," European Journal of International Security 3, no. 1 (February 2018): 45-68, https://doi.org/10.1017/eis.2017.13; Hilary Matfess, Women and the War on Boko Haram: Wives, Weapons, Witnesses (London: Zed Books, 2017); Laura Sjoberg, “Jihadi Brides and Female Volunteers: Reading the Islamic State's War to See Gender and Agency in Conflict Dynamics," Conflict Management and Peace Science, May 18, 2017, https://doi.org/10.1177/0738894217695050. May 18, 2017, 073889421769505, https://doi.org/10.1177/0738894217695050.","plainCitation":"Meredith Loken and Anna Zelenz, "Explaining Extremism: Western Women in Daesh," European Journal of International Security 3, no. 1 (February 2018

2 Ariel I. Ahram, "Sexual Violence and the Making of ISIS," Survival 57, no. 3 (May 4, 2015): 57-78, https://doi.org/10.1080/00396338 .2015.1047251; Phoebe Donnelly, "Wedded to Warfare: Forced Marriage in Rebel Groups," Fletcher School of Law and Diplomacy at Tufts University, 2019, https://search.proquest.com/docview/2247226328; Jacob Zenn and Elizabeth Pearson, "Women, Gender and the Evolving Tactics of Boko Haram," Journal of Terrorism Research 5, no. 1 (2014), http://jtr.st-andrews.ac.uk/article/828/707/.

3 See e.g. United Nations Security Council Resolution 2242 calling for attention to women, peace, and security in contexts of terrorism and violent extremism, http://unscr.com/en/resolutions/doc/2242. 
Given the confusion over many of the terms associated with a gender analysis, the chapter begins by summarizing some of the most useful concepts and terms related to violent extremism and gender. It then provides an overview of specific gender topics worth considering when embarking on a gender analysis based on how VEOs use gender and how preventing and countering violent extremism (P/CVE) implementers think about gender in their policies and programs. In the following section, I provide concrete guidance on gender analysis research design and dissemination strategies, sharing some of my own mistakes and successes in using a gender lens in field research in East Africa. I share brief insights from my own research, and in Appendix 2, I highlight more detailed examples of gender analysis in research projects in contexts of violent extremism from researchers based across Africa. The goal of this chapter is to motivate readers to undertake gender analyses on violent extremism not because of external pressure, but because doing so increases their own understanding, and that of others, working to address violent extremism.

\section{KEY CONCEPTS AND CONNECTIONS}

Definitions are important to scholars seeking to understand violent extremism and gender and how the two intersect. Extremism is one of the most challenging terms to define, and there is no definition agreed upon by scholars or policymakers. ${ }^{4}$ J.M. Berger defines violent extremism as "the belief that an in-group's success or survival can never be separated from the need for violent action against an out-group... the need for violence against an out-group is not conditional or situational." 5 Gender identities and sexual orientation, as emphasized by Berger, are a key focus for extremists. ${ }^{6}$ Since violent extremism is at its core focused on identity, and gender is an essential aspect of identity, the two concepts are closely linked.

Labels and definitions are especially important to clarify in research using a gender lens, because terms around gender are so frequently misused. Table 1 includes a listing of key terms and definitions that should be consulted and considered prior to undertaking any gender analysis.

\section{Table 1. Key terms and definitions}

Gender is a socially constructed identity related to women, men, boys, girls, as well as non-binary gender identities. I use socially constructed here to emphasize that there is nothing inherent about these labels, but instead they are interpreted by social dynamics and cultures. Gender does not just refer to people-language, TV shows, or news coverage can also be gendered. Gender also not only refers to relationships between males and females in a society, but to the construction, order, and power dynamics associated with femininity and masculinity within that society.

4 Terrorism has no agreed upon or precise definition with policymakers or scholarship, and labeling groups terrorists has political implications related to the U.S. State Department Foreign Terrorist Organization list. For these reasons, I use the term violent extremist organizations (VEOs) throughout this chapter rather than terrorists or terrorism.

5 J.M. Berger, Extremism (Cambridge: The MIT Press, 2018), 46. For more, see also: J.M. Berger, Researching Violent Extremism: The State of Play (Washington, D.C.: RESOLVE Network, 2019), https://doi.org/10.37805/rve2019.3.

6 Berger, Extremism, 40.

7 Carol Cohn explains that "gender is not simply a set of ideas about male and female people and their proper relations to each other; gender is, more broadly, a way of categorizing, ordering, and symbolizing power, of hierarchically structuring relationships among different 


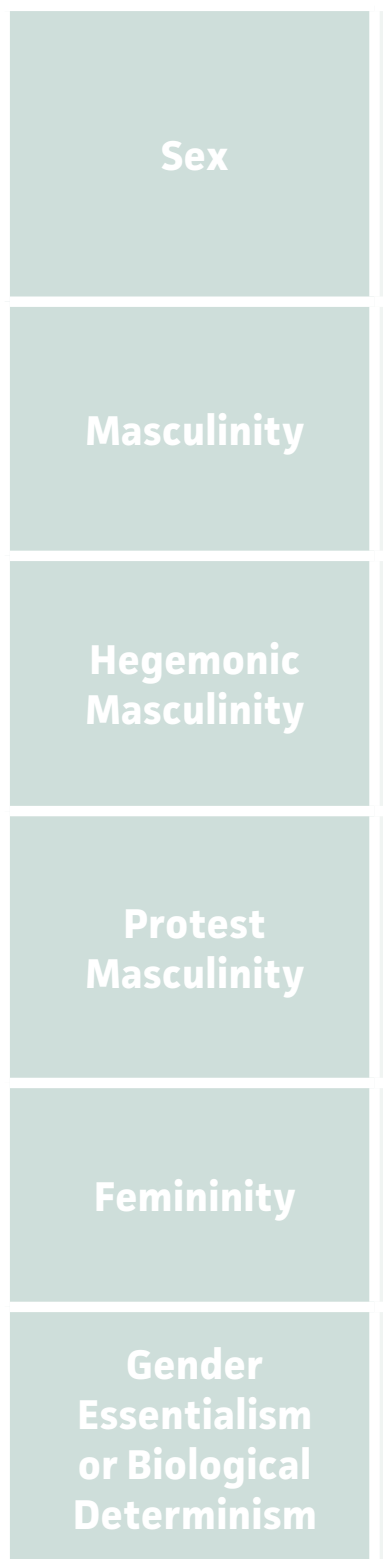

Sex is used to reference biological differences between men, women, and non-binary gender identities. Carol Cohn describes the relationship between sex and gender: "Gender insists that, however much is biologically given, societies construct a much greater set of differences than biology dictates, and that those socially constructed differences, in turn, legitimate a social order based on the domination of men over women, and some men over other men."

Masculinity as described by David Duriesmith is "a set of attributes that socially define the normal or acceptable range of behaviour for those of the male sex." ${ }^{\prime 9}$ Scholars often use the term masculinities to emphasize the range of behavior associated with the male sex that exist in a society.

Hegemonic masculinity is the form of masculinity that is most privileged and enjoys the most benefits and power in a society. ${ }^{10}$ Hegemonic masculinity is normative in that "men are taught they should aspire to and judge themselves by it, and state and society in turn judge and assess them against it..."11

Protest masculinity, as described by Duriesmith is, "a construct through which men are able to stake a claim to manhood through exaggerated masculine practices." ${ }^{12}$ Frequently men who engage in protest masculinity are frustrated with their inability to fulfill models of hegemonic manhood.

Interestingly, even within research focused on gender, there is less of a discussion about femininity and its definition. ${ }^{13}$ Adjusting Duriesmith's definition of masculinity ${ }_{1}^{14}$ we can think of femininity as a set of attributes that socially define the normal or acceptable range of behavior for the female sex.

Gender essentialism is the idea that "beings or things have innate characteristics that are largely unchanging." ${ }^{15}$ Similarly, biological determinism is defined as "the idea that our biology determines our destiny as genes simply play out their programs." ${ }^{16}$

categories of people, and different human activities symbolically associated with masculinity or femininity." See: Carol Cohn, "Women and Wars: Toward A Conceptual Framework," in Women \& War, ed. Carol Cohn (Cambridge: Polity, 2013), 3.

8 Cohn, Women and Wars, 7.

9 David Duriesmith, "Is Manhood a Causal Factor in the Shifting Nature of War?: The Case of Sierra Leone's Revolutionary United Front," International Feminist Journal of Politics 16, no. 2 (April 3, 2014): 241, https://doi.org/10.1080/14616742.2013.773718.

10 Duriesmith, "Is Manhood a Causal Factor in the Shifting Nature of War?," 243.

11 Chris Dolan, "Collapsing Masculinities and Weak States- A Case Study of Northern Uganda," in Masculinities Matter! Men, Gender and Development, ed. F Cleaver (London \& New York: Zed Books, 2002), 60.

12 Duriesmith, "Is Manhood a Causal Factor in the Shifting Nature of War?," 243.

13 Carrie Paechter, "Rethinking the Possibilities for Hegemonic Femininity: Exploring a Gramscian Framework," Women's Studies International Forum 68 (May 2018): 121, https://doi.org/10.1016/j.wsif.2018.03.005.

14 Duriesmith, "Is Manhood a Causal Factor in the Shifting Nature of War?," 241.

15 Laura J. Shepherd, ed., Critical Approaches to Security: An Introduction to Theories and Methods (London: Routledge, 2013$), 239$.

16 Joshua Goldstein, War and Gender: How Gender Shapes the War System and Vice Versa (Cambridge: Cambridge University Press, 2001), 52. 


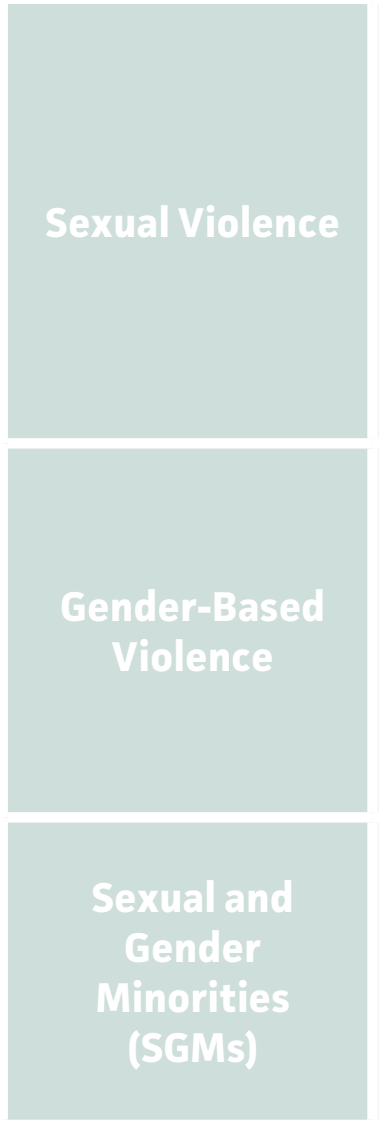

Sexual violence is a term focused on physical violence used frequently to denote rape but covers a broader subset of harm. One of the most useful explanations of sexual violence comes from the Sexual Violence in Armed Conflict (SVAC) dataset. This publicly available dataset tracks instances of conflict-related sexual violence committed by armed actors from 1989-2015. ${ }^{17}$ In the SVAC dataset sexual violence is defined, based on the explanation from The Rome Statute used by the International Criminal Court, and includes 1) rape, 2) sexual slavery, 3) forced prostitution, 4) forced pregnancy, and 5) forced sterilization or abortion. SVAC also uses the additions by the scholar Elisabeth Wood (2009) of 6) sexual mutilation and 7) sexual torture. ${ }^{18}$

Gender-based violence (GBV) is a broader term that includes sexual violence but also covers other forms of harm. The Inter-Agency Standing Committee's definition is helpful, geared towards humanitarian practitioners: "an umbrella term for any harmful act that is perpetrated against a person's will and that is based on socially ascribed (gender) differences between females and males." The Inter-Agency Standing Committee gives examples of GBV that include sexual violence but also practices such as female genital mutilation, honor killings, and widow inheritance. ${ }^{19}$

Sexual and gender minorities (SGMs), according to a definition in a report by International Alert is, "people whose sexual orientation, gender identity or sexual practices fall outside traditional norms. It may also refer to people who are perceived as such by others, resulting in similar social exclusion and vulnerability."20

Misunderstanding or misusing the above terms is problematic not only because it is inaccurate but because it can limit analysis. A fundamental misconception in this field and others is that a gender analysis is only about women. When a project or grant wants a "gender component," most researchers and practitioners read that as a need to include women. I hesitate to critique any approach that leads to the inclusion of women because it is important to be asking, "where are the women?"21 (and girls) when women are so frequently excluded from conflict analysis. Angela Raven-Roberts explains that "asking the question 'Where are the women?' not only helps us see the specificity of different women's lives in war; it also reveals that we need to look at war differently to see its gendered features and gendered impacts." 22

17 "Sexual Violence in Armed Conflict," accessed January 8, 2021, http://www.sexualviolencedata.org/.

18 For more information on the SVAC dataset, see: Dara Kay Cohen and Ragnhild Nordås, "Sexual Violence in Armed Conflict: Introducing the SVAC Dataset, 1989-2009," Journal of Peace Research 51, no. 3 (May 1, 2014): 418-28, https://doi.org/10.1177/0022343314523028.no. 3 (May 1, 2014

19 Inter-Agency Standing Committee, “Women, Girls, Boys, and Men: Diffeent Needs- Equal Opportunities," Gender Handbook in Humanitarian Action, December 2006, 12.

20 International Alert, "When Merely Existing Is a Risk: Sexual and Gender Minorities in Conflict, Displacement and Peacebuilding," $2017,5$.

21 The idea of asking this question in conflict environments was pioneered by Cynthia Enloe. See e.g.: Cynthia Enloe, Does Khaki Become You?: The Militarization of Women's Lives (Boston: South End Press, 1983).

22 Angela Raven-Roberts, "Women and the Political Economy of War," in Women \& Wars, ed. Carol Cohn (Cambridge: Polity Press, 2013), 39. 
Including women and girls should be one part of any gender analysis, but not its only component. When researchers are looking to better understand a context of violent extremism, it is useful to use a gender lens that not only looks at dynamics related to women and girls (and more broadly femininities) but also seeks to understand men, boys, and masculinities. The problem is not that we see the term gender and then think to incorporate women into the research project, but that the gender analysis stops there. Gender should not be seen as a code to simply add women-commonly referred to as "add women and stir"23 - without a deeper analysis of power dynamics or ideas about masculinities and femininities.

Another common misunderstanding relates to critiques around gender essentialism. It is not that ideas around gender essentialism are never or even rarely true, but that they stop the analysis. An example of a common gender essentialist notion is that there is something biologically distinct about women that makes them more peaceful than men and less likely to support violence. Challenging gender essentialism is not saying that there are not trends in which women are less likely to support violence than men, but that this is not because of innate biological characteristics. If there were innate biological characteristic making women more peaceful, then it would be impossible to explain the large groups of women who are violent or have participated in and supported wars (for example the women playing an active role in ISIS). ${ }^{24}$

Joshua Goldstein carefully analyzes whether there are links between war and gender that can be biologically explained. He writes that "to the extent that biology is destiny, that destiny is diversity... biological systems are extremely complex, flexible, and varied." ${ }^{25}$ In a gender analysis, rather than simply linking women and peace automatically, researchers can ask what might make this pattern true in the context they are examining. That questioning will lead to a more thoughtful and useful analysis rather than falsely assuming biological links between women and peace or men and violence. In conclusion, understanding key terms is a first step in a successful gender analysis because it requires researchers to consider different ideas about identities (like masculinity and femininity) as opposed to focusing on biological traits (sex) and making simplistic conclusions based on gender essentialism.

23 This phrase is often used when discussing flawed ways of incorporating gender into policy ideas and refers to the concept that instead of challenging existing ideas and engaging in a gender analysis, policymakers just add women into existing programs or ways of thinking. For a discussion of this concept, see e.g. Laura Shepherd, "Feminist Security Studies," in The International Studies Encyclopedia, ed. Robert Allen Denemark and Renée Marlin-Bennett (Wiley-Blackwell, 2017), https://www.oxfordreference.com/view/10.1093/ acref/9780191842665.001.0001/acref-9780191842665. 


\section{PROCESS, SKILLS, AND MINDSET: WHAT MAKES A GENDER ANALYSIS}

To understand the process of gender analysis, I find it useful to view it as a mapping exercise that:

1) involves asking questions about the different experiences of an environment for men, women, boys, and girls. These questions will focus on experiences, expectations, and relationships.

2) requires tracing power dynamics. Gender is a way of "structuring power," 26 and so it is important to understand who has access to different forms of power. In contexts of conflict where VEOs are operating, a common mistake is to only see power in terms of who is leading a group or who has access to weapons. It is useful to take a broader view of power and to recognize power differentials not only between men and women, but also between women, between men, between boys, and between girls.

3) recognizing intersectional identities (see textbox 1 below). Gender is one way to structure power, but one's access to power, in all of its forms, differs based not only on one's gender, but also on one's religion, class, education, race, ethnicity, age, and many other markers. A gender analysis does not treat women as a monolithic group but asks questions about different experiences of women, men, boys, girls, and SGMs.

4) is context dependent. Although different countries, states, and VEOs, have similarities and influence each other, it is important to avoid assuming that different environments will have the same gender dynamics. Expectations about femininity and masculinity vary based on different environments, time periods, and social groups. While it is useful to make comparisons across contexts, it is also essential to recognize where contexts diverge in gendered expectations. ${ }^{27} \mathrm{~A}$ gender analysis also examines patterns over time and recognizes that ideas about gender are changing and co-dependent.

5) challenges existing knowledge and conventions. A gender analysis can require a researcher to look for new or innovative sources of information. This is because, as J. Ann Tickner notes, "much of our knowledge about the world has been based on knowledge about men." ${ }^{28}$ One way to incorporate different data would be speaking to women in a society who might be ignored in research designs because they are not in positions of public power. Researchers might also have to be creative about getting information about women and hearing from women. ${ }^{29}$

Cohn, "Women and Wars: Toward A Conceptual Framework," 3-4.

For example, hegemonic masculinity (see table 1) has certain consistent traits across many contexts. Usually, hegemonic masculinity involves ideas about being able to provide for one's family or protect one's family. However, what this provision looks like and what type of protection a man is expected to provide will look different across contexts.

J. Ann Tickner, Gendering World Politics (New York: Columbia University Press, 2001), 4.

For example, in my own research, to get perspectives on women associated with VEOs, I read memoirs of women associated with the groups and reviewed court transcripts. Reading memoirs by women forcibly married into the Lord's Resistance Army allowed me to 


\section{Intersectionality}

A common question related to incorporating gender into a research design is why incorporate a gender lens instead of a race lens or an ethnicity lens. Researchers can and should examine different identity markers. Having a gender lens helps a researcher better use additional lenses related to identity. For example, general ideas about being a Muslim "person" are not as useful in understanding contexts of violent extremism on their own because there are different ideas about being a Muslim man or Muslim girl. Gender and religion can work together to enhance our understanding of the ways in which VEOs rely on identity. ${ }^{30}$

The concept of intersectionality is useful in explaining the ways in which different identity markers interact. Patricia Hill Collins and Sirma Bilge explain that:

Intersectionality is a way of understanding and analyzing the complexity in the world, in people, and in human experiences... When it comes to social inequality, people's lives and the organization of power in a given society are better understood as being shaped not by a single axis of social division, be it race or gender or class, but by many axes that work together and influence each other. ${ }^{31}$

The objective of incorporating a gender analysis into a research project is not to take away from the examination of other divisions or signifiers related to identity and power. Instead, the goal is to use gender analysis as one of many tools to understand dynamics in complex environments of violent extremism.

Importantly, gender analysis also entails specific preparations and requirements from the researcher, including:

1) Avoiding stereotypes or assumptions. This is not just because stereotypes are politically incorrect or offensive. As Chimamanda Ngozi Adichie explains, "the problem with stereotypes is not that they are untrue, but that they are incomplete. They make one story become the only story." ${ }^{32}$ When doing a gender analysis, researchers should be prepared to be surprised or proven wrong. When researchers rely on preconceived ideas, they miss key patterns (e.g. the use of women as spies or new ideas about masculinity focused on resisting VEOs).

understand how the women themselves interpreted life in the LRA including relationships with their co-wives, relationships with their children, and other details that might be commonly feminized and left out of academic research. See: Evelyn Amony, I Am Evelyn Amony (Madison, WI: The University of Wisconsin Press, 2015); Grace Acan, Not Yet Sunset: A Story of Survival and Perseverance in LRA Captivity (Kampala, Uganda: Fountain Publishers, 2017).

30 See e.g., Maleeha Aslam, Gender-Based Explosions: The Nexus Between Muslim Masculinities, Jihadist Islamism and Terrorism (Tokyo: United Nations University Press, 2012).

31 Patricia Collins Hill and Sirma Bilge, Intersectionality (Cambridge: Polity, 2016), 2.

32 Chimamanda Ngozi Adichie, The Danger of a Single Story, TED Talk, 2009, https://www.ted.com/talks/ chimamanda_adichie_the_danger_of_a_single_story?language. 
2) A willingness to see different forms of power, particularly of women. In my own research on gender and al-Shabaab, I had preconceived ideas about the ways in which Somali women were denied power in societies under al-Shabaab control. However, when I actually examined the dynamics in Kismayo, Somalia, a society ruled by al-Shabaab for five years, I realized that al-Shabaab saw women in Kismayo as powerful and threatening. In particular, al-Shabaab saw businesswomen as uniquely powerful and therefore tried to recruit, exploit, and extort them. ${ }^{33}$

3) Approaching the analysis with an open mind. Open-mindedness is especially important for researchers seeking to understand gender in a foreign context. As an outsider, researchers should be aware of their own positionality and bias ${ }^{34}$ and the ways in which ideas about power, masculinities, and femininities are inherently part of the way they see the world and understand other environments.

\section{GENDER AND VIOLENT EXTREMISM: KEY CONSIDERATIONS}

There are various ways in which VEOs rely on, manipulate, and are forced to consider gender dynamics, many of which are documented in a growing body of academic research and findings. ${ }^{35}$ While there are a variety of ways gender analysis can be featured in research on VEOs, there are a few categories that are particularly useful to consider when planning one's research.

\section{Gender and VEO membership and support}

Most analyses of VEOs assume that the group is composed of and made possible by men and boys. The most obvious questions asked when incorporating gender into the study of VEOs is whether women are members of the VEO. While a gender analysis is more than just adding women, it can be a useful starting point to challenging one's assumption about what a VEO looks like. In carrying out a gender analysis, it is useful to investigate women and girls' VEO membership and to also examine the ways in which the roles of women and girls' in VEOs influence those of the men and boys. For example, the "desperation hypothesis" asserts that VEOs may start including women and girls when recruitment is low. ${ }^{36}$ Recruiting women and girls not only adds new group members by broadening the recruitment pool to female members,

33 Donnelly, "Wedded to Warfare: Forced Marriage in Rebel Groups," 173-82.

34 Certain schools of research place a higher emphasis on "positionality" or the way in which a researcher's own identity relates to their research environment. Even for those outside of this positivist tradition, it is useful to closely examine the ways in which one's identity influences how they are viewed by interview participants.

35 Omer Aijazi and Erin Baines, "Relationality, Culpability and Consent in Wartime: Men's Experiences of Forced Marriage," International Journal of Transitional Justice, September 5, 2017, https://doi.org/10.1093/ijtj/ijx023; Dyan Mazurana, "Women, Girls, and Non-State Opposition Groups," ed. Carol Cohn (Cambridge: Polity, 2013); Matfess, Women and the War on Boko Haram.

36 Dara Kay Cohen, "Female Combatants and the Perpetration of Violence: Wartime Rape in the Sierra Leone Civil War," World Politics 65.03 (2013): 383-415. 
but can also encourage more men and boys to join a VEO because of ideas around masculinity and the perceived shame if women and girls are seen as braver than the men in society.

Usually, researchers start by asking if women and girls are in combat or leadership roles in a VEO. There have been detailed studies examining the roles women (and girls) play in different types of rebel groups. ${ }^{37}$ Women and girls in rebel groups perform multiple roles at once and therefore it can be hard to define women and girls' roles with one label. However, women and girls inside VEOs are usually labeled based on their feminized domestic roles such as "mothers" "wives," or "sex slaves." These simplistic labels limit analysis because mothers and wives in particular can also perform other key functions for VEOs. In contrast, researchers do not label male members of rebel groups only as "husbands" or "fathers." Research by Megan Mackenzie into the Revolutionary United Front (RUF) in Sierra Leone, for example, demonstrates that men perform violent combat roles alongside support roles. ${ }^{38}$

Women and girls' roles inside a VEO are commonly labeled "support roles" and are not viewed as essential to the group as masculinized combat roles. In their study of women and girls' roles in the Lord's Resistance Amy (LRA), Jeannie Annan and her co-authors found that 14 percent of females in the LRA were principally engaged in combat. Annan et al. explain:

While a rate of 14 percent females primarily engaged in combat may seem to suggest that females are performing non-essential roles within the LRA, such a simplistic assessment would be incorrect. We can compare this break-down to professional armies, such as the United States military, where only 15-20 percent of forces actually engage in active combat and the overwhelming majority serve crucial back-up and logistical roles in service and support units. ${ }^{39}$

The investigation of the ways in which women and girls support VEOs usually stops at an examination of whether women and girls are visible members of the organization in combat or leadership roles. This, in turn, can discount the important role they play in providing key support to a VEO. In my research into al-Shabaab's control of Kismayo, interview participants labeled women as the most important supporters of al-Shabaab. ${ }^{40}$ Even though women weren't combatants or even labeled "members" of al-Shabaab, they were essential to the group's survival due to their work in key areas related to finances and logistics.

37 Susan McKay and Mazurana, Dyan, Where Are the Girls? Girls in Fighting Forces in Northern Uganda, Sierra Leone, and Mozambique: Their Lives During and After War (Quebec: International Centre for Human Rights and Democratic Development, 2004); Mazurana, "Women, Girls, and Non-State Opposition Groups"; Jakana L. Thomas and Kanisha D. Bond, "Women's Participation in Violent Political Organizations," American Political Science Review 109, no. 03 (August 2015): 488-506, https://doi.org/10.1017/S0003055415000313; Alexis Henshaw, Why Women Rebel: Understanding Women's Participation in Armed Rebel Groups (New York: Routledge, 2017); Roos Haer and Tobias Böhmelt, "Girl Soldiering in Rebel Groups, 1989-2013: Introducing a New Dataset," Journal of Peace Research 55, no. 3 (May 2018): 395-403, https://doi.org/10.1177/0022343317752540.no. 3 (May 2018

38 Megan Mackenzie, Female Soldiers in Sierra Leone: Sex, Security, and Post-Conflict Development (New York: New York University Press, 2012).

39 Jeannie Annan et al., "The State of Female Youth in Northern Uganda: Findings from the Survey of War-Affected Youth (SWAY) Phase II," April 2008, 34-35, http://fic.tufts.edu/publication-item/the-state-of-female-youth-in-northern-uganda/.

40 Interview with female peace activist and soldier, September 24, 2017. 
Other scholars such as Sarah Elizabeth Parkinson and Alexis Henshaw have analyzed women in non-combat roles in violent organizations. ${ }^{41}$ Some examples of key roles that women and girls have fulfilled include spying, logistics, transporting weapons, hiding male members, cooking, cleaning, healthcare, education, recruitment, indoctrination, and fundraising. The types of roles and the individuals who fulfill them will vary based on context. It is possible the group has women and girls filling roles and performing tasks researchers did not even know a VEO needed. For example, traditional analyses of a VEO might not immediately consider the importance of feminized tasks like healthcare or educating new members. Researchers would also benefit from looking at the support roles men and boys fulfill for a VEO that might be ignored because of the focus on men and boys' combat roles. Discovering new requirements for the successful operation of a VEO is an example of the way in which gender analysis enhances researchers' understandings of VEOs.

Researchers also should not assume who fills what roles without examining the specifics of a context. For example, al-Shabaab has different rules about what they see as appropriate roles for women based on nationality and location..$^{42}$ Despite al-Shabaab's conservative ideas about female sexuality in areas under its control, the group partnered with local sex workers in Kenya to gain intelligence. ${ }^{43}$ Similarly, even though al-Shabaab prohibits women from operating businesses in areas under their control, they covertly rely on women in their fundraising efforts across the world. In Kismayo, businesswomen were essential to al-Shabaab. ${ }^{44}$ In the US, women in Minnesota have been charged with fundraising and sending money and supplies to al-Shabaab. ${ }^{45}$ The women convicted in the US did not see their roles as "support." In the trial transcript from the case one of the defendants describes her fundraising work as a form of jihad. ${ }^{46}$

41 Sarah Elizabeth Parkinson, "Organizing Rebellion: Rethinking High-Risk Mobilization and Social Networks in War," American Political Science Review 107, no. 3 (August 2013): 418-32, https://doi.org/10.1017/S0003055413000208; Henshaw, Why Women Rebel: Understanding Women's Participation in Armed Rebel Groups.but neglects to explain the timing or nature of participation. Support and logistical apparatuses play critical roles in sustaining armed conflict, but scholars have not explained role differentiation within militant organizations or accounted for the structures, processes, and practices that produce discrete categories of fighters, soldiers, and staff. Extant theories consequently conflate mobilization and participation in rebel organizations with frontline combat. This article argues that, to understand wartime mobilization and organizational resilience, scholars must situate militants in their organizational and social context. By tracing the emergence and evolution of female-dominated clandestine supply, financial, and information networks in 1980s Lebanon, it demonstrates that mobilization pathways and organizational subdivisions emerge from the systematic overlap between formal militant hierarchies and quotidian social networks. In doing so, this article elucidates the nuanced relationship between social structure, militant organizations, and sustained rebellion.","container-title":"American Political Science Review","DOI":"10.1017/S0003055413000208","I SSN":"0003-0554, 1537-5943","'issue":"3","journalAbbreviation":"Am Polit Sci Rev","language":"en","page":" 418-432","source":"'DOI.org (Crossref

42 Katharine Petrich and Phoebe Donnelly, "Worth Many Sins: Al-Shabaab's Shifting Relationships with Women," Small Wars and Insurgencies, September 19, 2019, https://doi.org/10.1080/09592318.2019.1649814.

43 Petrich and Donnelly, Worth Many Sins.

Donnelly, "Wedded to Warfare: Forced Marriage in Rebel Groups," 173-82.

Donnelly, Wedded to Warfare, 198-202.

United States of America v. Amina Farah Ali and Hawo Mohamed Hassan, Lori A. Simpson 18 (United States District Court District of Minnesota 2011). 
All VEOs rely on women and girls in some way to help their cause. Simply because women and girls' roles does not fall into existing categories does not mean they are less important to a VEO. If researchers go into an analysis of a VEO with the assumption that the group needs women and girls, they will better understand the group structure and operations.

\section{CONSIDERATIONS FOR RESEARCHERS:}

- Create a list of the types of activities the VEO you are studying needs to survive and consider who fills the different roles-men, women, boys, and girls-while accounting for contextual factors.

- Actively look for the ways in which women and girls are supporting a VEO.

- Pay attention to the labels used to describe the roles of women and girls in a group and assess whether they fully encompass the contributions of women and girls (for example, labeling someone a wife inside a VEO is often insufficient because wives are also doing other key tasks like handling logistics or providing healthcare support).

- Be aware of and resist preconceived ideas that women do not participate in violence on their own accord or that men and boys are not needed for specific non-combat roles.

\section{Organizational structure and supporter relationships}

Most VEOs have rules about how members should interact with each other. In security studies research, scholars ask questions focusing on how a VEO is organized and examine group leadership, whether the group is hierarchical or networked, and how cohesive the group is. ${ }^{47}$ An essential component of VEO success relates to how members interact with and support each other. A commonly ignored component of group organization relates to gender.

Gendered ideas can create specific hierarchies among and between men, women, boys, and girls in VEOs. For example, in the LRA in Uganda, ideas about masculinity and the relationship between men and boys affected the group structure. Higher ranking men in the LRA wanted to show their power over lower ranking men in the LRA. One key sign of status in the LRA was the number of wives a male commander had. ${ }^{48}$ Male commanders also controlled the marriages of other men in the group. ${ }^{49}$

In Boko Haram, women's marital status was a way to differentiate among women inside the group. Hilary Matfess writes that unmarried women in Boko Haram were called mustadafin or the weak and down-

47 See e.g., Peter Thompson, Armed Groups: The 21st Century Threat (Rowman and Littlefield, 2014) for ways to analyze armed groups.

48 Khristopher Carlson and Dyan Mazurana, Forced Marriage within the Lord's Resistance Army, Uganda (Medford, MA: Feinstein International Center, May 2008), 42.

49 Carlson and Mazurana, "Forced Marriage within the Lord's Resistance Army, Uganda." 
trodden..$^{50}$ Matfess notes that there was a lack of sexual abuse against the mustadafin and instead Boko Haram members saw these women as new members of their religious order in need of education. The treatment of the mustdafin is an interesting pattern to highlight in research, especially when most simplistic views of Boko Haram would assume sexual mistreatment of all women inside and around the group. However, a deeper examination of group gender dynamics reveals Boko Haram had distinct practices related to treating and managing women. This pattern also provides insights into Boko Haram's broader command and control structure and strategic objectives. Matfess explains:

The lack of sexual abuse against mustadafin suggests that insurgents identify their education as a strategic objective-the abducted women are not merely sexual slaves or a means of attracting young men to the insurgency (although this is certainly the case in a handful of cells). By and large, the women in the sect are considered members of a new religious order that is cultivating radical social change. ${ }^{51}$

Another example of the link between group organization and gender dynamics is that in many VEOs, the status of a woman or girl is based on the rank of her husband. For example, in Kismayo, interview participants noted that the only female members of al-Shabaab were the ones married to al-Shabaab members. ${ }^{52}$ The most powerful women in the group were the ones married to the most powerful ranking male commanders. The power of being a wife of a high-ranking al-Shabaab commander was gendered and often meant that women were granted additional resources, forms of physical safety, or control over other women and girls in al-Shabaab.

\section{CONSIDERATIONS FOR RESEARCHERS:}

- Any organizational analysis of a VEO will benefit from examining how different members are categorized and treated and what that reveals about the group's strategy and ideology, including along gender lines.

- When researchers seek to understand group power dynamics and organization, they should ask questions about what gives a man, woman, girl, or boy power inside the VEO and how that power is expressed.

\section{Interacting with non-members}

VEOs also consider gender in their rules (or lack of rules) on interacting with non-members in their areas of operation. Ariel Ahram writes about how ISIS uses different forms of sexual violence to assert supremacy over other rival armed groups and to build cohesion amongst its members. ${ }^{53}$ In particular, Ahram examines ISIS' enslavement of females (particularly Christian and Yazidi women and girls from the

50 Matfess, Women and the War on Boko Haram: Wives, Weapons, Witnesses, 119.

51 Matfess, Women and the War on Boko Haram, 120.

52 Donnelly, "Wedded to Warfare: Forced Marriage in Rebel Groups," 173-74.

53 Ahram, "Sexual Violence and the Making of ISIS," 67. 
Mosul area) and sexual violence committed against men and boys. ${ }^{54}$ ISIS was intentional in considering the implications of these forms of sexual violence, and ISIS's documents show a "profound concern for the legalities of sexual relationships with slaves and ensuing issues of paternity."

In contrast to ISIS' use of sexual violence, other VEOs may have strict regulations about the treatment of civilians, especially along sexual and gender lines. Elisabeth Jean Wood documents why and when certain armed groups ${ }^{56}$ refrain from sexual violence, even when opposition forces use it or the group uses other forms of violence against civilians. ${ }^{57}$ One of Wood's examples is the lack of sexual violence by The Liberation Tigers of Tamil Eelam (LTTE) in Sri Lanka, whose leadership banned the use of sexual violence. Wood argues that this ban is reflective of existing social norms that condemn sexual relations between unmarried persons, cross-caste relations, and rape of non-spouses. ${ }^{58}$ These two examples (ISIS and LTTE) demonstrate two very different models for the ways VEOs consider gender relations in their engagement with non-members.

Finally, in studying interactions of VEOs with civilians, and especially their use of violence against civilians, it is useful to analyze particular forms of violence against SGMs (see table 1). Emerging research by Meredith Loken and Jamie Hagen identify at least 23 violent groups that use targeted killings, sexual violence, torture, and abuses against SGMs. ${ }^{59}$ International Alert explains that nationalist and extremist propaganda often uses SGMs as scapegoats that VEOs claim are trying to destroy traditional cultures. ${ }^{60}$

\section{CONSIDERATIONS FOR RESEARCHERS:}

- Consider what forms of violence are used or not used by VEOs against boys, girls, men, and women as well as different groups of boys, girls, men, and women, who are not members of the group.

- Inquire how VEO leadership reacts to certain forms of violence against non-members. Ask, for example, what forms of violence are ordered, condoned, or prohibited against men, women, boys, and girls. ${ }^{61}$

- Analyze particular forms of violence against SGMs and why VEOs would target SGMs with certain forms of violence.

54 Ahram, "Sexual Violence and the Making of ISIS," 65-66.

55 Ahram, "Sexual Violence and the Making of ISIS," 67.

56 Wood's focus is not only VEOs but also different types of armed groups.

57 Elisabeth Jean Wood, “Armed Groups and Sexual Violence: When Is Wartime Rape Rare?," Politics and Society 37, no. 31 (2009): 131-62.

58 Wood, 148-49.

59 Meredith Loken and Jamie Hagen, "Violence Against Gender and Sexual Minorities During Conflict," Unpbulished Manuscript, 2020.

60 International Alert, "When Merely Existing Is a Risk: Sexual and Gender Minorities in Conflict, Displacement and Peacebuilding," 25.

61 For more information on the ways in which sexual violence can be a strategy or practice of an armed group, see: Dara Kay Cohen, Amelia Hoover Green, and Elisabeth Wood, "Wartime Sexual Violence: Misconceptions, Implications and Ways Forward," United Institute of Peace, Special Report 323, February 2013, https://www.usip.org/publications/2013/02/ wartime-sexual-violence-misconceptions-implications-and-ways-forward. 


\section{GENDER AND P/CVE PROGRAMS: KEY CONSIDERATIONS}

In contexts of violent extremism, a gender analysis is essential to inform P/CVE efforts. ${ }^{62}$ In this section, I devote more space to findings related to women and P/CVE, given the dangerous assumptions and misunderstandings associated with them. However, when scholars, policymakers, or program designers are examining the intersection of gender and $\mathrm{P} / \mathrm{CVE}$, they rarely look at men or masculinities. ${ }^{63}$ Therefore, a greater research agenda focusing on masculinities in P/CVE is needed.

The biggest weakness in most analyses of P/CVE is that they simplify women's roles in P/CVE and rely on essentialist ideas about women. ${ }^{64}$ Even the fact that scholars and policymakers think about "women" and $\mathrm{P} / \mathrm{CVE}$ broadly demonstrates a flaw in the analyses. Similar attention to the study of "men" and P/CVE is rare-instead research focuses on different types of men or boys and their varied relationships with VEOs. Two points stand out when considering women in P/CVE. First, a context-based analysis is indispensable when considering women's roles and relationships with VEOs and their societies. Second, women are a diverse group with different access to power and diverging interests across different contexts.

On one side is the common belief that women are powerful forces in the domestic sphere through their roles as wives and mothers. ${ }^{65}$ For P/CVE policymakers, women are often viewed as "an entry point to the private sphere of the home." ${ }^{66}$ Because of their leadership in the domestic sphere, women can be useful allies in P/CVE programs. However, citing two pilot projects on women and P/CVE, Chantal de Jonge Oudraat found that the women interviewed actually felt that their voices were not heard within their homes. ${ }^{67}$ Oudraat explains that "gender inequality is the greatest obstacle to women playing a role in preventing or countering violent extremism." ${ }^{68}$

62 Although I focus on P/CVE in this section (and the activities are closely linked) there is also useful research on gender and counterterrorism and counterinsurgency activities. See, for example, Fionnuala Ní Aoláin, "The 'War on Terror' and Extremism: Assessing the Relevance of the Women, Peace and Security Agenda," International Affairs 92, no. 2 (March 2016): 275-91, https://doi.org/10.1111/14682346.12552; Laleh Khalili, "Gendered Practices of Counterinsurgency," Review of International Studies 37, no. 4 (October 2011): 1471-91, https://doi.org/10.1017/S026021051000121X.

63 Unfortunately, programs related to P/CVE and masculinity have been criticized within the US. See, for example: Abdi Latif Dahir, "The Alt-Right Is Mad about a Trump Program Linking Violent Extremism in Kenya to Masculinity," Quartz Africa, accessed June 6, 2020, https://qz.com/ africa/1186457/trump-state-dept-spends-600000-on-kenya-masculinity-extremism-project/. Promundo is one organization that is doing ongoing work on masculinities and violent extremism. See: Abby Fried, "Promundo Partners with Vital Voices on New Initiative Examining Masculinities and Violent Extremism," August 27, 2018, https://promundoglobal.org/new-initiative-masculinities-violent-extremism/. Phoebe Donnelly, "Improving the Relationship Between WPS and CVE Policies," The Global Observatory, October 20, 2020, https://theglobalobservatory.org/2020/10/improving-relationship-between-wps-and-cve-policies/ Chantal de Jonge Oudraat, "Preventing and Countering Violent Extreimsm: The Role of Women and Women's Organizations," in A Man's World? Exploring the Roles of Women in Counter Terrorism and Violent Extremism (The Global Center for Cooperative Security, 2016$), 23$. Sophie Giscard d'Estaing, "Engaging Women in Countering Violent Extremism: Avoiding Instrumentalisation and Furthering Agency," Gender \& Development 25, no. 1 (January 2, 2017): 106, https://doi.org/10.1080/13552074.2017.1279823.

67 de Jonge Oudraat, "Preventing and Countering Violent Extreimsm: The Role of Women and Women's Organizations," 24. de Jonge Oudraat, 24. 
The second perspective on women and P/CVE emphasizes recognizing women's agency and interests (not just through their relationship with men). Jennifer Philippa Eggert writes that, "it should be acknowledged that women have agency, interests and skills just as men do. Women should be included in [counter-radicalization] processes as society cannot afford not to tap into their talent and expertise as practitioners, academics and leaders." 69 Additionally, women who might not be labeled as "practitioners," "academics," or "leaders" still have interests and opinions that are useful to consider in P/CVE policy, programs, and research.

Another concern with the view of women as the entry point into the home for P/CVE programs is that it can put women in danger and can place blame on women if their children or husbands are recruited by VEOs. ${ }^{70}$ The overemphasis on mothers as the main way women should be engaged in P/CVE programs is especially problematic. Sophie d'Estaing writes that "Over-focusing on the role of women as mothers in PVE/CVE is based on a narrow and over-simplistic understanding of the causes of extremism, and the solutions. In addition, it takes the focus away from the business of good governance and the role of the state in preventing violent extremism." ${ }^{11}$ The intersection of P/CVE and gender should not stop at recognizing on women's duties within the home but see women as a diverse group with agency and insight into violent extremism.

$\mathrm{P} / \mathrm{CVE}$ programs must be designed with the understanding that women can play key roles in VEOs. P/ CVE programs should consider women's motivations for joining VEOs for preventing recruitment in communities. ${ }^{72}$ Additionally, when designing deradicalization or amnesty programs for members of VEOs, policymakers should devise gendered strategies and tailor them to women who may also be leaving a VEO with children.

Finally, P/CVE programs are frequently created without consideration of security practices and policies of the states where they are being implemented. It is essential to recognize and evaluate state responses to violent extremism and the ways they effect men, women, boys, and girls differently. For example, in my own research on al-Shabaab in Kenya, many young male interview participants did not think violence from al-Shabaab was the biggest threat to their safety. Instead, several Kenyan interview participants were worried about extrajudicial killings and arrests by Kenyan police and security forces, framed under the guise of CT or P/CVE measures. ${ }^{73}$ Even policies that do not seem "gendered" have different impacts on different genders. For a further example, Lama Fakih examines the ways U.S. "soft" counterterrorism initiatives, specifically the anti-terrorism finance regime, negatively impacted women's rights in Somalia. ${ }^{74}$

69 Jennifer Philippa Eggert, "The Roles of Women in Counter-Radicalisation and Disengagement (CRaD) Processes," n.d., 6.

70 Giscard d'Estaing, “Engaging Women in Countering Violent Extremism," 107.

71 Giscard d'Estaing, 108.

72 For more on the ways and which men and women's motivations for joining VEOs differ see, Laura Sjoberg and Reed Wood, "People, Not Pawns: Women's Participation in Violent Extremism Across MENA," Policy Brief USAID, September 2015.

73 See e.g., Abdullahi Hassan, "Kenya must act now to stop extrajudicial executions," Amnesty International, September 9, 2018, https:// www.amnesty.org/en/latest/news/2018/09/kenya-must-act-now-to-stop-extrajudicial-executions/.

74 Lama Fakih, "8 Soft Measures, Real Harm," National Security, n.d., 190. 


\section{CONSIDERATIONS FOR RESEARCHERS:}

- Use a context-based approach to understand the agency of women across different environments.

- See women as political actors and do not confine their roles to the private sphere.

- Consider how counterterrorism policies or programs could affect men, women, boys and girls differently.

\section{GENDER ANALYSIS RESEARCH DESIGN}

Ideally, considerations about gender occur at the beginning of the process, throughout the research process, while writing, and while disseminating, publishing, or completing the project. This section highlights some of these considerations, including for research questions, ethics, and dissemination. The framing is based on feminist methodologies. ${ }^{75}$

\section{Research questions}

An essential part of incorporating gender into a research project is considering how the research topic could or does affect men, women, boys, and girls in different ways. In contexts of violent extremism here are some common questions that can supplement or be a part of the research design:

- How do VEOs manipulate, sustain, or break with norms around masculinity or femininity? Why do they choose this path?

- How does the behavior of VEOs affect men, women, boys, and girls differently?

- How do men, women, boys, and girls support or resist VEOs?

This is only a sample of potential questions, but each of these questions would enhance any research project related to VEOs. Embedded in each of these questions is the assumption that women's and girls' lives and experiences matter. ${ }^{76}$ Too often in research, especially around security issues, "women's experiences have been deemed trivial, or important only in so far as they relate to the experiences of men and the questions they typically ask." ${ }^{\prime 7}$ Part of the process of incorporating a gender lens will involve challenging assumptions about what kinds of questions are traditionally asked and what kinds of questions "matter."

See e.g, Brooke A. Ackerly, Maria Stern, and Jacqui True, eds., Feminist Methodologies for International Relations (Cambridge: Cambridge University Press, 2006).

76 Ackerly, Stern, and True, 25.

77 Ackerly, Stern, and True, 25. 


\section{Field research preparation and ethics}

Gender considerations should be a part of research preparation, especially for research with human subjects. Before starting a research project, consider how to reach multiple different types of participants. The perspectives of women and girls are often left out of research projects designed by male researchers focused on security. Sometimes there are logistical reasons for this, such as cultural norms around male researchers speaking to women alone. However, one way to overcome this barrier is by collaborating with a female researcher or research assistant. This extra step is not just about equity but gaining a more accurate picture of contexts of violent extremism. VEOs are conscious of the ways in which their behaviors and actions affect or are interpreted by women and girls, therefore researchers should also be considering this element. It can be helpful to detail information about the identity of interview participants without compromising anonymity, including gender (see Appendix 2 for detailed example).

Field researchers must consider their own status and identity and how it will be interpreted in the environments where they operate. It is important to be honest about how researchers' identities affect research participants. Feminist research stresses the importance of acknowledging one's identity and that "acknowledging the subjective element in one's analysis, which exists in all social science research, actually increases the objectivity of the research." ${ }^{\prime 78} \mathrm{It}$ is useful to also consider the type of access researchers are gaining to interview participants and how other researchers might lack this same type of access.

\section{Dissemination}

Finally, during the writing and publication phases, researchers again should ask in what ways the research project will affect men, women, boys, and girls differently and in what ways can they communicate their findings to men, women, boys, and girls. In my own research in northern Uganda, I began thinking about dissemination and the purpose of my research earlier than I expected. In discussions with former members of the LRA many women asked what my research would do to help them. I did not predict the ways in which I would struggle with how to answer this question and my answer was influenced by the context in northern Uganda. ${ }^{79}$

\section{CONCLUSION}

While gender analysis is a skill that takes practice, the essential components of a gender analysis rely on skills most researchers already have. In a gender analysis, a researcher asks questions (some of which they might not be able to answer in their project), traces power dynamics, looks at different types of identity markers and how they influence power, examines local contexts, and challenges existing knowledge and conventions. Finally, gender analysis helps researchers working on violent extremism produce stronger findings and policy recommendations.

78 Ackerly, Stern, and True, 27.

79 For more information on this process and my methodology overall see Donnelly, "Wedded to Warfare: Forced Marriage in Rebel Groups." 


\section{ApPendix 1 - Table Summarizing Research Participants}

TABLE 1: INTERVIEW PARTICIPANTS BY LOCATION ${ }^{80}$

\begin{tabular}{|c|c|c|c|}
\hline $\begin{array}{l}\text { Interview } \\
\text { location }\end{array}$ & $\begin{array}{l}\text { Number of } \\
\text { interviews }\end{array}$ & Breakdown by type of interview & $\begin{array}{c}\text { Breakdown by gender of } \\
\text { participant }\end{array}$ \\
\hline Kenya & 47 & $\begin{array}{l}25 \text { Key informant interviews (KIls) } \\
22 \text { Interviews with affected } \\
\text { community members }\end{array}$ & $\begin{array}{c}\text { KIls: } 11 \text { women, } 14 \text { men } \\
\text { Comm memb: } 13 \text { women, } 9 \text { men }\end{array}$ \\
\hline Somalia & 45 & $\begin{array}{l}40 \text { Interviews } \\
5 \text { Life stories }{ }^{81}\end{array}$ & $\begin{array}{c}34 \text { women }^{\star} \\
10 \text { men } \\
\text { *1 woman interviewed twice }\end{array}$ \\
\hline Uganda & 32 & $\begin{array}{l}32 \text { Interviews with affected } \\
\text { community members }\end{array}$ & $\begin{array}{l}21 \text { women } \\
11 \text { men }\end{array}$ \\
\hline $\begin{array}{c}\text { Key } \\
\text { informants } \\
\text { [by phone, } \\
\text { skype or } \\
\text { outside } \\
\text { key field } \\
\text { locations] }\end{array}$ & 24 & $\begin{array}{l}23 \text { Al-Shabaab focused } \\
1 \text { LRA focused }\end{array}$ & $\begin{array}{l}11 \text { women } \\
13 \text { men }\end{array}$ \\
\hline
\end{tabular}

\section{APPENDIX 2 - ILLUSTRATIVE EXAMPLES OF GENDER ANALYSIS IN CONTEXTS OF VIOLENT EXTREMISM}

Example 1: Integrating gender into research questions and design

Chitra Nagarajan's analysis of insecurity in the Zamfara region of northwestern Nigeria demonstrates how to integrate gender into research questions at the start of a project. Nagarajan conducted an analysis commissioned by the UK government with a focus on current conflict patterns and recommendations for ways to promote peace, public safety, and security. Nagarajan's list of research questions at the beginning of her report demonstrates how to incorporate gender into a broader research project on security. Her research questions are:

80 Donnelly, 56.

81 In the life stories, the field research team started with a guiding question, such as, "tell me about your life since the start of the clan conflicts in 1991?" This data is more focused on an individual's personal experiences and relationships. The field research team asked clarifying questions about the interview participants' experiences but did not ask the interview participant to provide input on general research topics. 
1) What are the root causes of violence and insecurity? What are the key grievances held by different groups and how do they manifest in violent and non-violent ways?

2) What is the impact of violence and insecurity on people (differentiated according to age, disability and gender)?

3) What are the gender dynamics around conflict and how do gender norms and realities drive violence and/or peace?

4) What are the factors (including government, security force and community action) bringing people together and/or promoting peace and stability?

5) Who are the key actors with influence, means and motivations to mobilize groups and resources into collective action for peace or for violence and what are links between them?

6) What are the potential trajectories, both positive and negative, around peace and security? ${ }^{82}$

The third question in Nagarajan's list clearly addresses gender dynamics, but there is an opportunity in each of her questions to consider different impacts and influences of men, women, boys, and girls.

Nagarajan also considered gender dynamics in her data collection. She interviewed men and women, but notes it was difficult to get even numbers of men and women as interview participants. She writes that "Ensuring gender balance was challenging as most civil servants, politicians, civil society members and people involved in violence are men. However, all women were interviewed individually, with more time spent with them." 83 Nagarajan speaks openly about the challenges in integrating women in equal numbers in her research design, but also discusses her efforts to overcome these challenges. There are cases where it may be difficult to have an equal number of men and women interviewed, but it is possible, as Nagarajan did, to get rich information from the women who one is able to interview. Nagarajan did not use the fact that women were not in traditional positions of public power as an excuse to not interview women. Instead, Nagarajan saw the fact that women were not in these forms of power as a research finding and a way to expand the research design.

\section{Example 2: Contextual analysis of local gender dynamics}

A detailed contextual assessment is useful for understanding the contexts in which VEOs are operating and gender is an essential part of a socioeconomic context. Rehema Zaid, a student and activist in Kenya, conducted a detailed gender analysis of Kwale County a coastal region in Kenya. Kwale County has a presence of local and international NGOs focused on P/CVE because it is a sight for recruitment by violent armed organizations. ${ }^{84}$ In her dissertation, Zaid conducts a gender analysis of Kwale county and

82 Chitra Nagarajan, “Analysis of Violence and Insecurity in Zamfara," February 2020, 6.

83 Nagarajan, 7.

84 Rehema Zaid Obuyi, Role of Women in Countering Violent Extremism in The Case of Kwale County, Kenya (Africa Nazarene University, 2020), 8. 
highlights patterns in Kwale county related to education levels across gender, land ownership dynamics, divorce rates, age of marriage, domestic violence and associated justice mechanisms, and female headed households.

Zaid asks the question of how the cultural and gender dynamics of the community of Kwale County would limit or enable women's participation in P/CVE activities. ${ }^{85}$ Zaid doesn't start her study with the assumption that women can participate in P/CVE activities, as many P/CVE programs created by the international community do. Instead, Zaid looks at community dynamics first to determine the best ways women can participate in P/CVE activities. Zaid even gives the possibility that this point in this community it may not be beneficial for women to engage in P/CVE activities.

She explains that the participation of women in P/CVE activities is the goal of her work in the region, but that goal can only be achieved "when predisposing and background factors such as policy, CSO community support and culture are supportive to their engagement/involved in P/CVE. Where these 3 factors are responsive, then women's participation in P/CVE will be attained, otherwise there shall be a scenario where women shy away from engaging in P/CVE." ${ }^{86}$ Leaving open the possibility that at this time women could not participate in P/CVE programs also demonstrates Zaid's flexibility and open-mindedness. The goal is not to keep women out of the P/CVE process, but to consider other steps to take in the community to support women's engagement.

\section{Example 3: Relying on Women's Expertise}

Fathima Badurdeen's study of women recruited into al-Shabaab in the coastal region of Kenya is an example of taking female interview participants experiences and voices seriously as a part of analyzing a VEO. Badurdeen interviews women who identified as returnees from al-Shabaab as well as key informants to describe the relationship between female recruiters and females who were recruited (some through deceptive measures). Through the use of biographical narratives, Badurdeen examines women's everyday lives, both in the public and private sphere. ${ }^{87}$

Badurdeen's article also includes lengthy quotes from her interviews, which helps amplify female interview participants' voices. Rather than having a researcher interpret what is important from the interview transcript or what the interview participant means, including text from the female interview participants gives them ownership over the message. The article provides essential insight into al-Shabaab recruitment, demonstrating the seriousness and energy of recruiters targeting women. Like each of the gender analyses in this section, Badurdeen's article does not only teach us about women and al-Shabaab, but provides a more complete understanding of the group's recruitment techniques and strategies. 


\section{BIBLIOGRAPHY}

Acan, Grace. Not Yet Sunset: A Story of Survival and Perseverance in LRA Captivity. Kampala, Uganda: Fountain Publishers, 2017.

Ackerly, Brooke A., Maria Stern, and Jacqui True, eds. Feminist Methodologies for International Relations. Cambridge: Cambridge University Press, 2006.

Adichie, Chimamanda Ngozi. The Danger of a Single Story. TED Talk, 2009. https://www.ted.com/talks/ chimamanda_adichie_the_danger_of_a_single_story?language.

Ahram, Ariel I. "Sexual Violence and the Making of ISIS." Survival 57, no. 3 (May 4, 2015): 57-78. https://doi.org/10.1080/00396338.2015.1047251.

Aijazi, Omer, and Erin Baines. "Relationality, Culpability and Consent in Wartime: Men's Experiences of Forced Marriage." International Journal of Transitional Justice, September 5, 2017. https://doi.org/10.1093/ijtj/ijx023.

Amony, Evelyn. I Am Evelyn Amony. Madison, WI: The University of Wisconsin Press, 2015.

Annan, Jeannie et al. "The State of Female Youth in Northern Uganda: Findings from the Survey of War-Affected Youth (SWAY) Phase II." April 2008, 34-35. http://fic.tufts.edu/publication-item/the-state-of-female-youth-in-northern-uganda/.

Aoláin, Fionnuala Ní. “The 'War on Terror' and Extremism: Assessing the Relevance of the Women, Peace and Security Agenda.” International Affairs 92, no. 2 (March 2016): 275-91. https://doi.org/10.1111/1468-2346.12552.

Aslam, Maleeha. Gender-Based Explosions: The Nexus Between Muslim Masculinities, Jihadist Islamism and Terrorism. Tokyo: United Nations University Press, 2012.

Badurdeen, Fathima. "Women and Recruitment in the Al-Shabaab Network: Stories of Women Being Recruited by Women Recruiters in the Coastal Region of Kenya." The African Review 45, no. 1 (2018).

Berger, J.M. Extremism. Cambridge: The MIT Press, 2018.

Berger, J.M. Researching Violent Extremism: The State of Play. Washington, D.C.: RESOLVE Network, 2019. https://doi.org/10.37805/rve2019.3.

Bond, Kanisha, Kate Cronin-Furman, Meredith Loken, Milli Lake, Sarah E. Parkinson, and Anna Zelenz. "The West Needs to Take the Politics of Women in ISIS Seriously." Foreign Policy, March 4, 2019. https://foreignpolicy.com/2019/03/04/the-west-needs-to-take-the-politics-of-women-in-isis-seriously/.

Carlson, Khristopher, and Dyan Mazurana. Forced Marriage within the Lord's Resistance Army, Uganda. Medford, MA: Feinstein International Center, May 2008.

Cohen, Dara Kay. “Female Combatants and the Perpetration of Violence: Wartime Rape in the Sierra Leone Civil War.” World Politics 65, no. 3 (2013): 383-415.

Cohen, Dara Kay, Amelia Hoover Green, and Elisabeth Wood. "Wartime Sexual Violence: Misconceptions, Implications and Ways Forward." United Institute of Peace, Special Report 323, February 2013. https://www.usip.org/publications/2013/02/ wartime-sexual-violence-misconceptions-implications-and-ways-forward.

Cohen, Dara Kay, and Ragnhild Nordås. "Sexual Violence in Armed Conflict: Introducing the SVAC Dataset, 1989-2009." Journal of Peace Research 51, no. 3 (May 1, 2014): 418-28. https://doi.org/10.1177/0022343314523028.

Cohn, Carol. "Women and Wars: Toward A Conceptual Framework." In Women \& War, edited by Carol Cohn, Cambridge: Polity, 2013.

Dahir, Abdi Latif. "The Alt-Right Is Mad about a Trump Program Linking Violent Extremism in Kenya to Masculinity." Quartz Africa, accessed June 6, 2020. https://qz.com/africa/1186457/trump-state-dept-spends-600000-on-kenya-masculinity-extremism-project/.

de Jonge Oudraat, Chantal. "Preventing and Countering Violent Extreimsm: The Role of Women and Women's Organizations." In A Man's World? Exploring the Roles of Women in Counter Terrorism and Violent Extremism. The Global Center for Cooperative Security, 2016.

d’Estaing, Sophie Giscard. "Engaging Women in Countering Violent Extremism: Avoiding Instrumentalisation and Furthering Agency." Gender \& Development 25, no. 1 (January 2, 2017). https://doi.org/10.1080/13552074.2017.1279823.

Dolan, Chris. “Collapsing Masculinities and Weak States - A Case Study of Northern Uganda." In Masculinities Matter! Men, Gender and Development, edited by F Cleaver, London \& New York: Zed Books, 2002.

Donnelly, Phoebe. "Wedded to Warfare: Forced Marriage in Rebel Groups." Fletcher School of Law and Diplomacy at Tufts University, 2019. https://search. proquest.com/docview/2247226328.

Donnelly, Phoebe. "Improving the Relationship Between WPS and CVE Policies." The Global Observatory, October 20, 2020. https://theglobalobservatory. org/2020/10/improving-relationship-between-wps-and-cve-policies/.

Duriesmith, David. "Is Manhood a Causal Factor in the Shifting Nature of War?: The Case of Sierra Leone's Revolutionary United Front." International Feminist Journal of Politics 16, no. 2 (April 3, 2014). https://doi.org/10.1080/14616742.2013.773718.

Eggert, Jennifer Philippa. "The Roles of Women in Counter-Radicalisation and Disengagement (CRaD) Processes." n.d.

Enloe, Cynthia. Does Khaki Become You?: The Militarization of Women's Lives. Boston: South End Press, 1983.

Fakih, Lama. "8 Soft Measures, Real Harm.” National Security, n.d.

Fried, Abby. "Promundo Partners with Vital Voices on New Initiative Examining Masculinities and Violent Extremism." August 27, 2018. https://promundoglobal.org/new-initiative-masculinities-violent-extremism/. 
Goldstein, Joshua. War and Gender: How Gender Shapes the War System and Vice Versa. Cambridge: Cambridge University Press, 2001.

Haer, Roos, and Tobias Böhmelt. “Girl Soldiering in Rebel Groups, 1989-2013: Introducing a New Dataset." Journal of Peace Research 55, no. 3 (May 2018): 395-403. https://doi.org/10.1177/0022343317752540.

Hassan, Abdullahi. “Kenya must act now to stop extrajudicial executions." Amnesty International, September 9, 2018. https://www.amnesty.org/en/latest/ news/2018/09/kenya-must-act-now-to-stop-extrajudicial-executions/.

Henshaw, Alexis. Why Women Rebel: Understanding Women's Participation in Armed Rebel Groups. New York: Routledge, 2017.

Hill, Patricia Collins, and Sirma Bilge. Intersectionality. Cambridge: Polity, 2016.

Inter-Agency Standing Committee. "Women, Girls, Boys, and Men: Diffeent Needs - Equal Opportunities." Gender Handbook in Humanitarian Action, December 2006, 12

International Alert. "When Merely Existing Is a Risk: Sexual and Gender Minorities in Conflict, Displacement and Peacebuilding." 2017.

International Alert. "When Merely Existing Is a Risk: Sexual and Gender Minorities in Conflict, Displacement and Peacebuilding."

Khalili, Laleh. “Gendered Practices of Counterinsurgency." Review of International Studies 37, no. 4 (October 2011): 1471-91. https://doi.org/10.1017/ S026021051000121X.

Loken, Meredith, and Anna Zelenz. “Explaining Extremism: Western Women in Daesh.” European Journal of International Security 3, no. 1 (February 2018): 45-68. https://doi.org/10.1017/eis.2017.13.

Loken, Meredith, and Jamie Hagen. "Violence Against Gender and Sexual Minorities During Conflict.” Unpbulished Manuscript, 2020.

Matfess, Hilary. Women and the War on Boko Haram: Wives, Weapons, Witnesses. London: Zed Books, 2017.

Mackenzie, Megan. Female Soldiers in Sierra Leone: Sex, Security, and Post-Conflict Development. New York: New York University Press, 2012.

Mazurana, Dyan. “Women, Girls, and Non-State Opposition Groups.” In Women \& War, edited by Carol Cohn, Cambridge: Polity, 2013.

McKay, Susan, and Mazurana, Dyan. Where Are the Girls? Girls in Fighting Forces in Northern Uganda, Sierra Leone, and Mozambique: Their Lives During and After War. Quebec: International Centre for Human Rights and Democratic Development, 2004.

Nagarajan, Chitra. “Analysis of Violence and Insecurity in Zamfara." February 2020, 6.

Obuyi, Rehema Zaid. Role of Women in Countering Violent Extremism in The Case of Kwale County, Kenya. Africa Nazarene University, 2020.

Paechter, Carrie. "Rethinking the Possibilities for Hegemonic Femininity: Exploring a Gramscian Framework." Women's Studies International Forum 68 (May 2018). https://doi.org/10.1016/j.wsif.2018.03.005.

Parkinson, Sarah Elizabeth. “Organizing Rebellion: Rethinking High-Risk Mobilization and Social Networks in War.” American Political Science Review 107, no. 3 (August 2013): 418-32, https://doi.org/10.1017/S0003055413000208.

Petrich, Katharine, and Phoebe Donnelly. "Worth Many Sins: Al-Shabaab's Shifting Relationships with Women." Small Wars and Insurgencies, September 19, 2019. https://doi.org/10.1080/09592318.2019.1649814.

Raven-Roberts, Angela. "Women and the Political Economy of War." In Women \& Wars, edited by Carol Cohn, Cambridge: Polity Press, 2013.

"Sexual Violence in Armed Conflict." Accessed January 8, 2021. http://www.sexualviolencedata.org/.

Shepherd, Laura J. ed., Critical Approaches to Security: An Introduction to Theories and Methods. London: Routledge, 2013.

Shepherd, Laura. "Feminist Security Studies." In The International Studies Encyclopedia, edited by Robert Allen Denemark and Renée Marlin-Bennett, Wiley-Blackwell, 2017. https://www.oxfordreference.com/view/10.1093/acref/9780191842665.001.0001/acref-9780191842665.

Sjoberg, Laura, and Reed Wood. “People, Not Pawns: Women's Participation in Violent Extremism Across MENA.” Policy Brief USAID, September 2015.

Sjoberg, Laura. "Jihadi Brides and Female Volunteers: Reading the Islamic State's War to See Gender and Agency in Conflict Dynamics." Conflict Management and Peace Science, May 18, 2017. https://doi.org/10.1177/0738894217695050.

Thomas, Jakana L., and Kanisha D. Bond. “Women's Participation in Violent Political Organizations.” American Political Science Review 109, no. 03 (August 2015): 488-506. https://doi.org/10.1017/S0003055415000313.

Thompson, Peter. Armed Groups: The 21st Century Threat. Rowman and Littlefield, 2014.

Tickner, J. Ann. Gendering World Politics. New York: Columbia University Press, 2001.

United Nations Security Council Resolution 2242, http://unscr.com/en/resolutions/doc/2242.

United States of America v. Amina Farah Ali and Hawo Mohamed Hassan, Lori A. Simpson 18 (United States District Court District of Minnesota 2011).

Wood, Elisabeth Jean. “Armed Groups and Sexual Violence: When Is Wartime Rape Rare?.” Politics and Society 37, no. 31 (2009): 131-62.

Zenn, Jacob, and Elizabeth Pearson. “Women, Gender and the Evolving Tactics of Boko Haram.” Journal of Terrorism Research 5, no. 1 (2014). http://jtr.st-andrews.ac.uk/article/828/707/. 